\title{
O QUE NOS DIZ A ARTE KAXINAWA SOBRE A RELAÇÃO ENTRE IDENTIDADE E ALTERIDADE ?*
}

\author{
Elsje Maria Lagrou
}

\begin{abstract}
A intenção deste texto é demonstrar, através do diálogo com vários antropólogos que pensaram a questão da arte enquanto linguagem específica, como a perspectiva kaxinawa sobre o entrelaçamento da alteridade e identidade no tecido da vida se expressa na sua arte, tanto na pintura corporal e tecelagem, onde a alternância entre figura e fundo ressalta a presença simultânea da figura e de seu contrário corolário, como na arte plumária dos homens, onde a relação entre simetria e assimetria recebe um tratamento diferente embora complementar ao da arte feminina.
\end{abstract}

\section{Identidade e alteridade ${ }^{1}$}

"A capacidade de imitar, e imitar bem, é, em outras palavras, a capacidade de tornar-se outro." (Walter Benjamin apud Taussig 1993:19)²

A prática diária e ritual kaxinawa revela um complexo e dinâmico dualismo que questiona, insistentemente, uma definição substancialista de identidade e de diferença. Por meio de recorrentes inversões de papéis e posições no sistema de nominação e no ritual, e através dos persistentes paradoxos elaborados pelo discurso, a questão da identidade e alteridade aparece como tema central na ontologia kaxinawa.

Esta questão não é pertinente apenas para os Kaxinawa, podendo ser encontrada na quase totalidade dos grupos de língua pano. Os Pano são conhecidos na literatura etnográfica como especial mente "obcecados" pelos estrangeiros e por todos os tipos de "outros" (Erikson 1986; Keifenheim 1990; 1992; Calavia 1995). O intrigante conceito nawa, para o qual há variações na maioria desses grupos, é paradigmático da ambigüidade pano com relação à definição de fronteiras entre o "eu" e o "outro". 
Nawa pode ser usado para denotar uma "verdadeira" alteridade: inimigos, brancos e os mitológicos Inka (deuses canibais). Pessoas ou animais (caça) aparecem referidos em canções rituais como nawa, significando, aqui, inimigo. Nawa é também usado para nomear em conjunto distintos grupos pano (os Nawa da área J uruá-Purus, que incluem Kaxinawa, Yaminawa e outros nawas), ou como parte do etnônimo atribuído a Pano vizinhos, significando, nesse contexto, "povo": caxi (morcego) nawa, yami (machado) - nawa, mari (cotia) - nawa etc. O termo pode, ainda, denotar uma das metades ou seções de doadores de nomes no interior do próprio grupo (como entre os Yaminawa, M arubo e A mahuaca), apresentando o mesmo significado que o pluralizador -bu³.

Esse fato demonstra que, nas línguas pano, um mesmo conceito pode ocupar diferentes posições em uma escala que vai da completa alteridade e hostilidade até o pólo do "nós" mais inclusivo, denotando pertencimento a uma subdivisão interna à própria comunidade. Isso não quer dizer, entretanto, que nawa perca seu caráter relacional intrínseco. Não importa o quanto se aproxime do "eu", o termo sempre significará alguém que não "eu mesmo". Isso explica por que não pode ser usado como auto-referência ou para se referir a alguém com quem se deseja estabelecer um laço de proximidade e de co-pertencimento grupal. N esse sentido, nawa permanece sendo o "outro", embora um "outro" que pode, facilmente, ser transformado no "mesmo", se adotado um "outro" ponto de vista.

A "noção filosófica do que é similar e diferente" (Overing 1986:142) parece ter especial interesse para os ameríndios (e para os americanistas), aparecendo em vários sistemas classificatórios na forma de complementaridade e interdependência entre os sexos, e expressando-se em diferentes formações sociológicas e cosmológicas, em dualismos tanto diametrais quanto graduais, em toda a extensão das terras baixas da América do Sul (Lévi-Strauss 1991; M aybury-Lewis 1979; Viveiros de Castro 1986; Carneiro da Cunha 1978; Overing 1984; Clastres 1974; 1982).

Os Pano têm um sistema de metades ritualmente elaborado mas seu dualismo não é diametral: uma das metades parece ser mais exterior que a outra4. A diferença criada através das classificações dualistas entre os Pano é gradual e, hipoteticamente, reversível, e não dicotômica ou exclusiva do tipo: "A não é B". Entre os Kaxinawa, o pertencimento a uma das metades e às quatro seções matrimoniais é condicionado pelos nomes pessoais. Em virtude de os nomes poderem ser classificados em grupos definidos por geração, sexo e metade, funcionam enquanto critério de afiliação étnica na escolha dos termos de parentesco para classificar um pa- 
rente previamente desconhecido. Nomes e metades são guias importantes para a eleição de parceiros matrimoniais 5 . A complementaridade entre as metades é profusamente expressa no desempenho das atividades rituais.

Resta, ainda, o desejado e proibido "outro" real que vem de fora da ordem social controlada. Este, a divindade Inka, constitui o terceiro elemento na escala gradativa que define "eu" e "outro" e é o afim potencial, hipotético, onipresente no mito, no ritual, nas canções, nas visões, nos sonhos e nas fantasias. $\mathrm{O}$ "outro" real funciona enquanto valor cosmológico e escatológico englobante que nunca é, e nunca poderá ser, presentificado através de uma aliança de casamento nesta vida terrena. Os Kaxinawa são endogâmicos, quando possível se casam dentro da aldeia. Esta prática reflete sua ideologia concêntrica de casar, acima de tudo, com parente em vez de com afins (o que não os impede, evidentemente, de se casar com seus afins terminológicos, os primos cruzados). Esta perspectiva encontra respaldo em uma ideologia amazônica da consubstancialidade, vista como produzida através da co-residência e da comensalidade, que fazem as pessoas se sentirem como pertencentes a um mesmo grupo'.

A mais inclusiva autodefinição para um Kaxinawa é nukun yuda, que significa "nosso mesmo corpo": um corpo que é produzido coletivamente por pessoas que vivem na mesma aldeia e que compartilham a mesma comida. São os parentes próximos que provocam um forte sentimento de pertencimento e, quando estão ausentes, é sentida sua falta, expressa pelo termo manuaii, palavra usada para definir a saudade de um parente próximo, do mesmo modo como se designa a sensação física e vital da necessidade de água. Água é vital para o corpo assim como parentes são vitais para constituir o "eu". Isto pode ser ilustrado pela seguinte sentença proferida por Antônio Pinheiro, Kaxinawa: “Quem não sente falta dos seus parentes, como se sente falta de água, não é gente. É como um yuxin que fica vagando por aí" 7 .

Os laços que ligam uma pessoa a seus parentes constituem o "eu" kaxinawa. Essa rede de laços vitais é criada no tempo, pelo viver junto, pela comensalidade, por compartilhar determinadas substâncias vitais, os banhos medicinais e a pintura corporal nos rituais. Secreções corporais e cheiros afetam diretamente as pessoas com as quais se vive. Uma intervenção, direta ou indiretamente praticada, que transforme o corpo de alguém, afeta sua mente, pensamentos e sentimentos. Nesse sentido, quando os Kaxinawa estão falando do corpo, estão se referindo ao "eu" e às transformações do corpo, às vezes descritas como incidindo sobre a "alma". 
Pode-se dizer, desse modo, que o "eu" kaxinawa inclui, não apenas seu próprio corpo mas também seu parente próximo ${ }^{8}$. Isto explica por que uma pessoa que não reside mais na aldeia se torna mais e mais distante e, com o passar do tempo, transforma-se em um não-parente ou, até mesmo, em um não-Kaxinawa, aos ol hos de quem estava habituado a chamá-la de parente. Essa pessoa pode mesmo ser transformada em não-índio, nawa, ou até perder os atributos humanos, tornando-se, portanto, um ser que vagueia, yuxin, um ser sem forma - o que implica não apenas uma mudança na aparência corporal, mas no comportamento e nos pensamentos. Yuxin, nesse contexto, significa um ser perdido no mundo, sem laços, sem lugar para ir, sem pessoas que se "lembrem" dele.

Essa transformação gradual de um ser propriamente humano em um estranho e, finalmente, em um não-humano ou não-ser (quando deixa de existir totalmente), ocorre no tempo, através do comportamento e pelo contágio com a alteridade. A mesma lógica se aplica à doença. Estar doente significa estar em um estado transformativo de perda do "eu", adquirindo alteridade. A doença não é produzida por uma única causa mas por uma combinação de forças internas e externas. As forças predatórias provenientes do exterior tornam-se ativas dentro de uma pessoa por meio da comida ingerida ou dos odores inalados. Podem entrar, também, quando uma pessoa se encontra em um estado emocional vulnerável, quando se sente triste ou só. O processo de se tornar outro é complexo e quase sempre reversível. Alguém deixa de ser um "verdadeiro" Kaxinawa por não residir mais em uma aldeia, por viver muito tempo em lugares diversos, o que resulta na aquisição de um corpo diferente e, através dessa diferença corporal, em uma diferenciação também dos sentimentos, pensamentos, valores e memórias. Ser propriamente humano, portanto, no sentido kaxinawa, significa viver em comunidade com os parentes próximos.

Essa endogamia de aldeia, apoiada em uma forte ideologia da consubstancialidade, é complementada por uma cosmologia verticalizada, próxima do modelo araweté (Tupi), em que o desejo da afinidade potencial é projetado no post mortem (Viveiros de Castro 1986). Uma vez a pessoa morta, o yuxin do olho9 adquire novo corpo e novas roupas, capazes de transformá-lo em um ser imortal que poderá se casar e viver com aqueles que os vivos representam como o pólo extremo e absoluto do perigo, o "inconvivível" outro: os Inka.

Como entre outros povos amazônicos, a ordem social e o sistema de parentesco como uma unidade interior composta por elementos de uma mesma classe (pessoas com um mesmo corpo que compartilham pensa- 
mentos e hábitos) são englobados pela ordem cosmológica da alteridade, do canibalismo e da predação, e sua relação com esta última ordem de fenômenos é temporal: humanos estão no caminho de se tornarem outros e este processo, para as sociedades araweté e kaxinawa, será somente completado depois da morte.

A complexidade da relação entre semelhança e diferença na ontologia kaxinawa é expressa na centralidade desse tema na mitologia, na organização da prática ritual e no discurso silencioso da arte visual, assim como no quadro de referência da prática classificatória cotidiana dos seres e das coisas. O pensamento social kaxinawa não projeta a diferença para fora da sociedade, como fazem muitas sociedades amazônicas que tentam inventar uma vida a ser vivida somente na companhia dos iguais/ parentes, através da evitação da terminologia de afinidade e da domesticação de todos os poderes e substâncias tomados do exterior. Em função de uma aguda preocupação com a predação e a possível retaliação implicadas em todos os atos criadores de vida e comunidade, esses povos escoIheram neutralizar as expressões imanentes de violência, reduzindo, desse modo, o perigo envolvido em qualquer atividade produtiva (Overing 1985; 1993). Por outro lado, a ideologia kaxinawa não introjeta totalmente a diferença, tratando-a como se ela emanasse do interior, como faz aparentemente a complementaridade do dualismo oposicional do sistema de metades e da vida social e cerimonial dos $\mathrm{J} \mathrm{ê}^{10}$.

A ontologia kaxinawa considera a alteridade como uma dificuldade, em última instância fatal, um inescapável e insolúvel paradoxo: o único modo de concebê-la é tornar-se, a si próprio, "outro". Sem se tornar outro, ao menos temporariamente, o ser está constrangido a permanecer entre iguais, possibilidade esta encerrada nos tempos míticos da semelhança incestuosa e da separação dos seres em diferentes tipos. O contato com o "outro", radicalmente concebido, leva a conflitos e mortes. É apoiando-se nesta concepção que os Kaxinawa encontraram modos de "mímesis" e transformação, diferentes maneiras de "trocar de pele", atualizando, assim, uma possibilidade de alteridade que nada mais é que a preparação para a jornada final e a transformação, depois da morte, em símbolo de semel hança, máxima realização do humano, e de extrema alteridade, o deus Inka, que canibaliza os humanos, os leva à morte e os separa dos seus.

Esta figura mítica se comporta como um canibal ou onça em relação àqueles que considera demasiadamente diferentes, mas como cônjuge e força civilizatória para os Kaxinawa, agora mortos, que se tornaram iguais a ele, isto é, bonitos e luminosos como o eterno Inka, habitante do mundo 
celeste. Os Kaxinawa, enquanto vivos, são presas potenciais do Inka, mas quando mortos e vivendo nas aldeias celestes, são alimentados por este.

A produção e a reprodução da alteridade através da semelhança, e da semelhança através da alteridade, processo observado por outros pesquisadores das sociedades pano (veja Erikson 1986; 1992; Keifenheim 1990; 1992; Calavia 1995; Townsley 1988), constituem a base do argumento deste texto que concebe o artifício do dualismo, pelo menos para os Kaxinawa, como um meio de se tornar um em lugar de dois, e de se tornar "mesmo" e "outro". Divisões ontológicas são posicionais e temporárias nessa visão de mundo: são relativas e cambiáveis, não essenciais ou substanciais, nunca fixas. As diferenças não constituem oposições entre termos mutuamente exclusivos, mas são de natureza gradual.

A duplicidade da figura do Inka é um bom exemplo do esquema de semelhança na diferença, ou do dualismo, usado para conceitualizar a unicidade de um ser. No começo de minha pesquisa, questões sobre o Inka eram respondidas de modo explicitamente dualista: um era o Inka pintsi, Inka faminto por carne, um povo do tempo histórico/mítico que canibalizava os Kaxinawa; o outro, totalmente diferente, me era apresentado como Inka kuin, nosso Inka, o real ou o próprio Inka, em cuja aldeia o yuxin do olho passa a viver depois da morte. Com o tempo, no entanto, tornou-se claro que a dualidade na figura do Inka não se referia a uma duplicação de personagens nomeados pelo mesmo termo Inka, mas a uma duplicidade sempre possível de pontos de vista e relações, visto que esses dois Inka são um; lados diferentes de uma mesma moeda. Inka pode ser tanto o avarento canibal quanto o cônjuge provedor, dependendo da relação que se estabelece com ele: afinidade real ou afinidade potencial. Dessa maneira, as definições tanto de nawa como de Inka sugerem uma leitura do dualismo kaxinawa a partir da noção de perspectiva, e uma versão kaxinawa do que veio a ser chamado de 'perspectivismo ameríndio'11.

O dualismo consiste mais em um valor englobante para o pensamento kaxinawa do que em uma discussão classificatória sobre identidade. Quando o 'perspectivismo' é introduzido, o dualismo ganha um aspecto contextual e um caráter dinâmico. A ontologia kaxinawa postula a dualidade inerente e intrínseca de todos os seres. Todos os viventes e a própria vida no mundo dependem da mistura de forças e qualidades opostas. Todos os seres e coisas do mundo são resultado do ritmo e controle dessa mistura e apresentam a dualidade fenomenológica do conteúdo e do continente, esqueleto e pele, semente e invólucro.

Qualquer separação absoluta de classes diferentes significa ausência de vida, enquanto sua mistura induz ao movimento, que indica, por 
sua vez, vida. O mito de origem da ordem do mundo começa com a criação do dia e da noite. Antes de o mundo existir, essas qualidades estavam, como todas as qualidades, latentes mas separadas, "dormindo em suas respectivas cavernas". Era o tempo antes do tempo, quando nada mudava porque nada era misturado; não havia interação de espécie al guma entre qualidades dos seres de diferentes classes. A diferença foi criada através do ato de sua revelação, quando os seres primordiais abriram as cavernas do amanhecer e do anoitecer: a caverna onde o sol se escondia e a outra que guardava o frio em seu interior (Capistrano de Abreu 1941). A criação torna acessível aos sentidos as possibilidades do ser.

O que distingue esse processo de vida não é a diferença entre agência e ausência de agência, sujeito e objeto, mas uma diferença de contexto e poder relativo. Existindo simultaneamente em ambos os níveis da matéria e do imaterial, cada ser é capaz de agência, percepção e subjetividade. Para ter forma e consistência, a matéria precisa estar imbuída de yuxin, visto que "sem yuxin, todas as coisas tornam-se pó, somente casca vazia. Você toca nelas e elas se dissolvem e então você vê nada mais que cinzas, pó" (Antônio Pinheiro, Kaxinawa). A definição de um ser como sendo um verdadeiro yuxin ou uma mera "coisa" depende, novamente, de uma escala gradual em que $A$ necessariamente partilha da qualidade de $B$, em vez de um par diametralmente oposto em que para ser $A, A$ não pode ser $B$.

Quem define a situação é aquele que inicia o processo de troca e/ou predação, processo que transforma as partes envolvidas; este tende a ser um princípio que guia a classificação dos seres ao longo de uma escala do menos ao mais perigoso. Todo intercurso, toda troca de palavras ou substâncias, desencadeia um processo que, por sua vez, produz outros processos, fazendo assim com que o mundo esteja em permanente movimento.

Podemos concluir que se, no dualismo kaxinawa, A necessariamente envolve $B$, as oposições presentes no pensamento e na ação existem apenas para serem dissolvidas. Essa dissolução pode ser alcançada seguindo uma lógica temporal (encontrada na mitologia kaxinawa e na escatologia) ou uma lógica da predação (Lagrou 1998). N esse sentido, o problema da semelhança e da diferença na ontologia kaxinawa parece encontrar solução na afirmação de uma continuidade entre os termos opostos, em vez de em sua mútua exclusão. Por isso, a diferença não pode ser definida simplesmente em termos de complementaridade de categorias, mas sim de um movimento em direção à sua integração. $\mathrm{O}$ dualismo kaxinawa é assim menos uma classificação das coisas e dos seres do que um problema a exigir resolução. 


\section{A arte kaxinawa: um discurso silencioso sobre a relação entre identidade e alteridade}

“Se quisermos entender as regras éticas de uma sociedade, é a estética que devemos estudar" (Leach 1954:12).

Os Kaxinawa compartilham a visão perspectiva recentemente discutida na literatura etnológica, que os põe como caçador para alguns e como caça para outros, ou então, como caçador e caça para os mesmos seres em diferentes momentos e contextos, e estendem essa relação para plantas e árvores (como fazem as mulheres Achuar, de um modo mais radical, com as "plantas canibais") (Descola 1987:239-265).

A pesar de expressar, na mitologia, posições reversíveis entre presa e predador, a oposição ontologicamente fundante para os Kaxinawa divide o mundo de um modo diferente. O tema central aqui é a relação entre o "eu" e o "outro", huni (nós, propriamente humanos) e nawa (outro, inimigo potencial). Esta relação não envolve uma reversibilidade de posições em que sujeito significa agência e objeto passividade, mas uma intersubjetividade em que ambas as posições apresentam as qualidades de agência e de subjetividade. Isto parece explicar por que o termo nawa pode denotar, ao mesmo tempo, o predador mais poderoso e a vítima humanizada de uma expedição de caça: ele é um inimigo que significa, ao mesmo tempo, vítima e agressor. Como resultado desse processo, delineia-se uma ontologia em que os seres assumem todos uma posição subjetiva; a diferença aqui é entre o conhecido, a agência propriamente humana (social), e o desconhecido, a agência imprópria e anti-social. Em um nível sociológico o problema é, mais uma vez, o da afinidade.

Alteridade, para os Kaxinawa, não significa falta de humanidade, subjetividade ou agência, mas ininteligibilidade e diferentes modos de perceber e ol har as coisas, implicando o relacional e, nunca, o essencial e o substancial. Os deuses canibais Inka, os brancos e os inimigos não são vistos enquanto intrinsecamente canibais incontroláveis; eles se comportam deste modo não em função de qualquer qualidade inerente mas em virtude de um determinado tipo de relação, uma relação de excesso de alteridade, mais que um "eu" pode suportar. Mais uma vez, para ser capaz de lidar com a alteridade deve-se aprender a tornar-se outro ou imitar o ser outro no sentido de captar seu ponto de vista no mundo e, assim, ganhar poder sobre a situação interativa.

Outro elemento presente em todas as relações - e neste ponto retornamos a Lévi-Strauss (1991) e Dumont (1980) - é que, nas relações anta- 
gônicas entre seres diferentes (e todos os seres são diferentes), há sempre um desequilíbrio de poder, mesmo que este seja hipoteticamente reversível. Esta visão é expressa pelo lugar que os gêmeos ocupam no pensamento ameríndio. N esta mitologia, os gêmeos nunca são pensados como idênticos ${ }^{12}$. A diferença entre eles está posta desde o início, derivando do fato incontestável, e pleno de conseqüências para os Kaxinawa, de que um dos gêmeos nasce primeiro. Disto derivam todos os tipos de diferenças vistas sempre em termos graduais. Entre os gêmeos existirá o menor e o maior, o mais forte e o mais fraco e, aspecto que todos os meus informantes insistiram em frisar, o sortudo e o azarado. Esta lógica da diferença gradual, do mais velho e do mais moço, do menor e maior, repousa na base do dualismo de metades e de toda conceitualização de complementaridade nas relações e no mundo.

No pensamento ameríndio, a idéia de duplo implica, portanto, diferença. Duplicidade na singularidade é possível, o que não é possível é a igualdade duplicada. A idéia é a criação de seres de uma mesma classe, o que quer dizer dotados de similaridade suficiente para garantir o entendimento entre eles, sem que constituam clones ou réplicas. Uma simetria perfeita nunca será encontrada no mundo. Esta idéia se manifesta na arte kaxinawa. A simetria na arte é retificada por um pequeno detal he assimétrico que expressa a idéia de identidade distinta. É o detalhe, a dissonância, que dá vida ao trabalho artístico, assim como à vida em si mesma. Desse modo, o estilo gráfico kaxinawa pode ser visto como a visualização do valor social da autonomia pessoal que se manifesta em sutis detalhes idiossincráticos, escondidos no padrão global de simetria e igualdade. O efeito studium-punctum descrito por Roland Barthes (2000:44-49) aplica-se a este estilo gráfico.

O studium, ou o discurso dominante, seria neste caso a repetição de el ementos iguais em um ritmo simétrico e o al to valor dado à execução delicada de finas linhas paralelas. $O$ estilo gráfico kaxinawa é caracterizado pelo horror vacui: toda a superfície dos corpos pintados deve ser coberta com desenhos e nenhuma linha pode ficar aberta. $O$ padrão pode ser cortado onde a superfície pintada termina, sugerindo uma continuação para além daquele suporte. Isto demonstra a função do desenho como algo que une mais do que separa (ver fotos le 2).

Dessa maneira, a noção de 'tecido da vida', concebido enquanto entretecimento de elementos iguais (isto é, de seres que ocupam a mesma posição no sistema), cada um pertencendo a uma de duas metades contrastantes (figuras escuras alternadas com figuras claras), é evocada no tecido que mostra como o entrelaçamento repetido e sistemático de opos- 


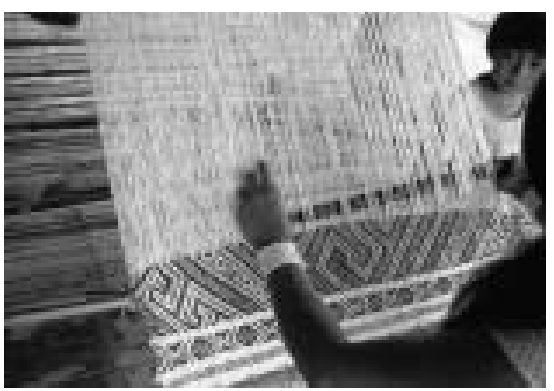

1 Tecelagem de blusa de uso ritual

2 Mesma peça quase terminada Fotos de Elsje Lagrou

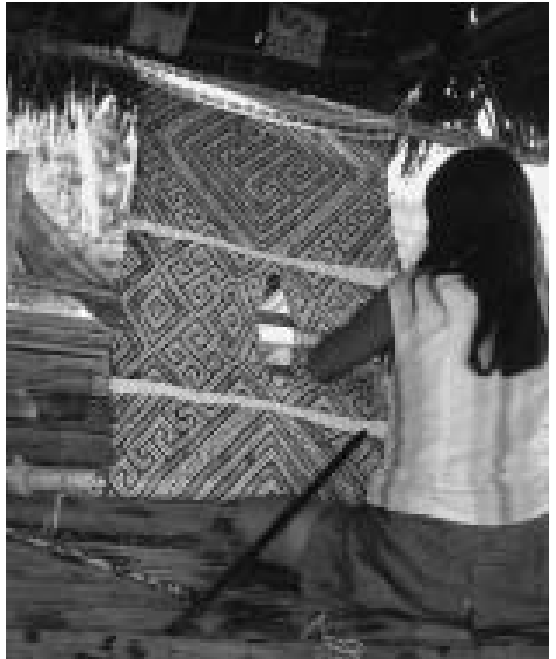

tos complementares, distintos na cor mas iguais na forma, pode formar um padrão infinito. Assim, um tecido reúne elementos opostos mas ao mesmo tempo essencialmente iguais do ponto de vista da forma, substância e qualidade: motivos pretos e brancos são feitos do mesmo al godão, e inu e dua (as metades), ou homem e mulher, são ambos feitos dos mesmos fluidos corporais e agência yuxin.

O tecido desempenha a função de uma pele, contendo o espaço corporal no seu interior, filtrando e protegendo, ao mesmo tempo em que conecta o que está dentro com o que está fora. A mesma lógica associa a pele com as paredes da casa (chamadas kene, assim como o desenho gráfico), e o teto esférico com a cúpula do cosmos. Se o conceito de corpo (yuda) pode ser estendido a nukun yuda (nosso corpo), incluindo parentes próximos que partilham comida e teto (antigamente, grandes malocas podiam hospedar uma aldeia inteira), o fato de a casa ter sido escol hida como metáfora daquilo que contém o corpo segue como conseqüência lógica. As aldeias dos yuxibu ${ }^{13}$ são, da mesma maneira, imaginadas como conjuntos fechados de corpos e comunidades: são esféricas e fechadas e a entrada é uma porta. $O$ que liga esses fenômenos é o conceito de desenho (kene), um desenho que nunca existe como conceito abstrato mas que adere sempre a alguma coisa ou é incorporado em um suporte. Desenho é aquilo que separa o dentro e o fora do 'corpo' (ou mundo), assim como aquilo que constitui o meio de comunicação entre ambos os lados.

Desse modo, voltando à análise formal do estilo e do significado que este revela quando a forma é associada às estruturas principais que orien- 
tam a concepção kaxinawa do mundo, chegamos à noção de uma unidade sintética na dualidade, uma estrutura básica que expressa a característica principal da vida na terra. Conseqüentemente, o discurso manifesto do estilo, seu studium, enfatiza a igualdade essencial de todos os elementos, em sintonia com uma filosofia social que reage contra qualquer exacerbação de diferenças (todos os humanos são mais ou menos iguais, como o são as unidades do desenho), e que realça a ligação dos seres humanos com os demais elementos do cosmos cujos corpos são todos cobertos com a mesma malha de desenho. Torna visível, igualmente, o fato de todo corpo ser composto da reunião das qualidades inu e dua, bem como da conjunção das qualidades femininas e masculinas. O studium, em suma, trata da homogeneidade e coerência, e expressa a idéia da comunidade como um corpo social (nukun yuda) coberto pela mesma 'pele' (roupa) cultural ou rede de caminhos (as unidades mínimas de desenho são chamadas de 'caminhos', bai) que cobre todo o mundo domesticado (ou explorado, conhecido).

O punctum, ou detalhe esteticamente agradável, por outro lado, pertence ao domínio dos eventos imprevisíveis e da criatividade pessoal. Por este motivo, um ângulo a mais, em uma das múltiplas gregas que compõem um padrão, perturbará a simetria perfeita da estrutura e chamará a atenção para a autoria da peça de arte, assim como para o fato de, mesmo em um padrão geral de similaridade, nada ser produzido duas vezes sem que sofra uma pequena transformação no processo de reprodução. Do mesmo modo que o ser humano é único por causa da sua história pessoal e singularidade corporal, todo produto do trabalho humano é único na técnica e na concepção, e o artista kaxinawa nunca deixa de marcar essa singularidade por meio de um detal he sutil. Assim, a qualidade de ser único apesar de parecido é conscientemente feita visível através da introdução de pequenas distorções nos padrões clássicos, distorções estas que dão à peça o seu caráter.

O punctum é, portanto, a dissonância próxima do detalhe invisível, a surpresa necessária para a dinâmica visual, aquilo que dá vitalidade estética ao todo, um ponto assimétrico no interior de uma simetria. É necessário que exista certa homogeneidade nos elementos visuais para que a pequena diferença seja capaz de tocar nossos ol hos. A arte kaxinawa explora elegantemente o entrelaçamento do studium e do punctum. Dessa maneira, para um pano tecido ou para uma face pintada, a primeira impressão será a de uma superfície coberta por um padrão geométrico constituído pela infinita repetição de unidades iguais. Um olhar mais acurado, porém, perceberá que um dos losangos do padrão colméia contém 
um círculo interior a mais que os outros. Este é o punctum, e sua ocorrência na arte kaxinawa é sistemática ${ }^{14}$. Outro exemplo desse fenômeno pode ser visto nos colares. Se um colar de contas, por exemplo, é composto pela alternância de seis contas vermel has e seis azuis, em algum lugar no meio do colar se encontrará uma conta branca perturbando, propositalmente, a perfeita simetria e repetição do padrão.

Esta marca sutil da personalidade do artista, em peças fortemente caracterizadas por um estilo, parece congruente com o modo como os Kaxinawa experienciam a vida: a criação da comunidade é fruto do forte desejo de viver tranqüilamente com os parentes próximos, tornando a sociabilidade possível através da valorização da autonomia pessoal e do respeito pela autonomia alheia.

Outra característica que aumenta a particularidade e a qualidade distinta de uma peça de tecido desenhado é a transformação suave de um padrão em outro. Essas transformações ocorrem somente em panos decorados com motivos que cobrem uma superfície extensa ${ }^{15}$. O fenômeno me foi explicado da seguinte maneira: "Na pele de Yube tem todos os desenhos possíveis. A cobra tem vinte e cinco mal has, mas cada uma dá em vários outros desenhos. No fim das contas, todos os desenhos pertencem à mesma pele da jibóia." (Agostinho Kaxinawa) Edivaldo, jovem liderança, expressou-se em termos similares: "O desenho da cobra contém o mundo. Cada mancha na sua pele pode se abrir e mostrar a porta para novas formas. Há vinte e cinco manchas na pele de Yube, que são os vinte e cinco desenhos que existem."

Em contraste com o que ocorre na tecelagem, a unicidade na pintura corporal ou facial não é de difícil obtenção; surge a partir do suporte, assim como do estilo da mão que pinta: cada face refletirá o mesmo padrão diferentemente, e a superfície complexa força o desenho a adaptar seus ângulos em curvas, acompanhando o relevo do corpo pintado. Dessa maneira, o desafio da pintura corporal ou facial não reside tanto no detalhe assimétrico (que, no entanto, aparece), mas na habilidade em cobrir a superfície irregular sem que se percam a coerência do desenho e a regularidade da distância entre as linhas que compõem o padrão (ver fotos 3 e 4).

O mesmo desafio à manutenção do equilíbrio entre a coerência do padrão e a aplicação em um suporte irregular foi notado por Lévi-Strauss (1955:205-227) na sua análise da pintura facial kadiwéu e por Gow (1988) na sua análise do desenho piro. Gow sugere uma correlação entre a complexidade da relação dinâmica entre os elementos gráficos e plásticos no estilo artístico e o suporte primário no qual o estilo se desenvolveu, con- 

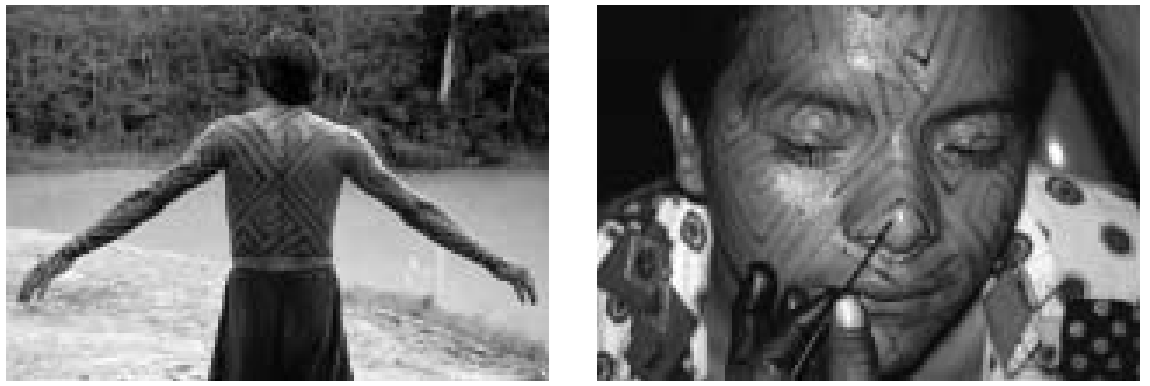

3 Pintura corporal

4 Pintura facial

Fotos Elsje Lagrou

cluindo que esta poderia ser a explicação da grande elaboração do desenho na tecelagem kaxinawa, por um lado, e da complexidade do sistema de desenho da pintura corporal piro, por outro. As mulheres kaxinawa eram principal e primeiramente tecelãs; as mulheres piro, desenhistas. A mesma hipótese foi sugerida por Dawson (1975) para explicar a ênfase dos Kaxinawa sobre a tecelagem em relação à pintura corporal. Este argumento em defesa da determinação técnica de toda elaboração artística lembra o de Boas no seu clássico Primitive Art (1928), estudo que critica o cego projetar ("reading-into") de significados simbólicos em unidades de desenho, método usado sem avaliação crítica em estudos superficiais pelos estudiosos da arte étnica do seu tempo. O tratamento da arte como diretamente denotativa não leva a resultados coerentes. A razão para este fracasso, entretanto, não reside no fato de as formas serem desprovidas de sentido (puramente sensoriais e não conceituais ou cognitivas), mas sim de a linguagem visual comunicar sua mensagem de modo diferente da lógica denotativa e 'simbólica'.

$\mathrm{Na}$ arte plumária, por outro lado, uma arte masculina, o desequilíbrio e assimetria são mais explícitos. Aqui o objetivo parece ser o de encontrar um delicado equilíbrio através do desequilíbrio, sugerindo desse modo o constante movimento das penas que, embora normalmente da mesma cor e provenientes do mesmo pássaro, são propositalmente diferentes em tamanho para produzir uma certa ondulação. Caudas compostas de materiais diversos (conchas, unhas de vários tipos de mamíferos, penas de diferentes cores etc.) podem estar penduradas no cocar de forma a aumentar o caráter idiossincrático da peça, e são designadas como dau (decoração ou "remédio" do cocar). Como toque final, rabos de arara são postos no topo. Estes longos rabos são presos ao cocar, envergados pelo peso de um pequeno pedaço de cera de abelha atado às suas extremidades. $\mathrm{Na}$ cera 
são fixadas pequenas penas recortadas. O resultado é um equilíbrio sutil e móvel de peças desiguais porém similares.

As faixas de bambu que servem de suporte ao equilíbrio móvel das penas, por sua vez, são caracterizadas por uma disposição do desenho no suporte que é menos dinâmica do que a encontrada nas pinturas faciais e nos tecidos, onde o centro de gravidade do desenho nunca é no meio do campo. A descentralização do desenho na tecelagem e na pintura corporal aumenta a impressão de sua continuação para além das bordas do campo decorado, como se o desenho estivesse cortado16, enquanto o desenho na coroa de bambu é disposto em fileiras sem cruzamento diagonal. No cocar, o equilíbrio assimétrico das penas é complementar à simetria da decoração do anel que os segura. O suporte do cocar pode também ser recoberto por um tecido de algodão. N este caso, igualmente, o motivo da base é rígido, como se para compensar a falta de simetria no topo.

Para o Txidin (festa do gavião-real), fabrica-se a 'roupa do gaviãoreal', que cobre o corpo inteiro - cabeça, peito e costas - com adornos plumários feitos com as penas deste pássaro. Estas penas, difíceis de obter, são guardadas como possessões raras e preciosas pelas pessoas que conseguem matar a ave, mas nem por isso serão usadas por elas. A comunidade inteira contribui com penas para a fabricação dos trajes do líder do canto e do seu aprendiz. Cada pessoa que se junta como aprendiz ao líder, terá direito de se cobrir com o traje durante a performance. $O$ traje é assim uma roupagem ritual que pertence à comunidade, sendo montado unicamente por ocasião do ritual. É o produto das contribuições de cada um dos caçadores da aldeia que teve a sorte de obter penas de harpia. Destarte, contribui para a coesão social, em vez de se tornar meio de ostentação de propriedade ou habilidade privadas.

Cocares são igualmente usados no ritual de fertilidade Katxanawa. Aqui, cada participante veste seu próprio cocar que, por esta razão, se presta com facilidade a meio de competição e demonstração de prestígio social. A análise feita por Rabineau de uma coleção de adornos plumários acompanhada de notas de campo, reunida por Kensinger nos anos 60 , revela interessantes ligações entre os julgamentos estético e social17. Os cocares fabricados pela liderança da aldeia e seu filho são considerados belas obras, demonstrando domínio da técnica e delicadeza na execução e escolha do material. O trabalho do filho, especialmente, é "elogiado pela economia de penas e elegância no desenho" (Rabineau 1975:96). Seu comportamento é discreto, e sua ambição de suceder o pai não é abertamente expressa. O produtor do cocar dominou a estética da arte plumária e da etiqueta social. 
O caso de Muiku era diferente. Muiku era o rival do líder da aldeia e não parecia guardar suas ambições para si. Utilizou-se para o Katxanawa das penas da harpia, apropriadas unicamente no contexto do Txidin e do Nixpupima e, porque não as possuía em quantidade suficiente para completar um cocar (ninguém, evidentemente, colaboraria com ele nessa situação), teve que misturá-las com as penas de jacamim. Esta mistura e o uso de penas demasiadamente prestigiosas no contexto errado foram esteticamente desaprovados. Um outro cocar confeccionado por M uiku foi igualmente desaprovado: apesar de demonstrar boa técnica, ele teria exagerado, dessa vez, no uso de penas amarelas, e por esta razão seu trabaIho foi considerado "excessivo".

Os exemplos dados por Rabineau ilustram bem a conexão entre regras sociais e gosto estético. O significado da estética da arte plumária é, entretanto, mais complexo. Penas têm yuxin (Kensinger 1995:247-258) e precisam, por isso, ser usadas na combinação e contexto apropriados, e pela pessoa certa. Ao contrário do que sugere Rabineau, não é a liderança da aldeia que usa as penas da harpia como signo de prestígio e autoridade política, mas o líder do canto e seus aprendizes (um dos quais pode ser, mas não necessariamente é, o líder da aldeia). O uso dessas penas se dá em contexto ritualmente controlado. Elas formam parte do traje do representante ritual do Inka no Nixpupima e no Txidin. Pelo fato de o dono das penas - o Inka na sua manifestação da harpia - ser chamado para o terreiro da aldeia e ser assim considerado presente durante as festividades, a pessoa que usa o traje desse personagem necessita saber os cantos certos que acompanham a performance, do contrário se expõe a um perigo da ordem da 'yuxinidade', ou seja, relacionado aos donos não-humanos das penas usadas.

Não é a liderança da aldeia, nem o xamã, que se especializa no ofício de lidar com as penas da harpia e de usá-las, mas o líder do canto, por causa da óbvia ligação entre essas e sua especialidade: a arte de memorizar e executar os cantos rituais, uma arte que se considera como tendo sido aprendida com os pássaros. Esses cantos são ligados ao Inka, enquanto outros cantos (como os yuan entoados durante as sessões com ayahuasca) são ligados a Yube (anaconda mítica) e à visualização ritual das realidades ligadas aos yuxin e yuxibu.

Percebo, dessa maneira, que as regras que guiam a combinação de cores e de materiais são mais complexas do que as que visam somente a demonstração de prestígio social. A través da categoria dau (encanto, remédio, veneno), que se aplica à roupa assim como às decorações usadas pelo líder do canto, fica claro que o uso de certos emblemas carregados 
de prestígio social tem conseqüências que implicam um compromisso ritual e não somente a posição social.

Retornando ao estilo de pensamento perspectivo expresso na tecelagem, ressalta a recorrência dessa mesma atitude artística em outros sistemas gráficos amazônicos. A qualidade cinética da troca de perspectiva entre figura e fundo, observável nos padrões labirínticos típicos da tecelagem e da cestaria de muitas sociedades amazônicas, foi percebida na análise da "arte abstrata" ameríndia por Peter Roe e David Guss.

Roe chamou a atenção para a correspondência entre esse estilo artístico e um estilo de pensamento. O autor argumenta que a "ambigüidade visual" dos desenhos shipibo (grupo pano do Peru) corresponde a uma "ênfase na ambigüidade mental" (Roe 1987:5-6). "Ambigüidade mental" é uma expressão problemática que pode ser facilmente substituída por "perspectivismo" sem, contudo, transformar o significado primordial dessa analogia. Para Roe, a significação da ambigüidade perspectiva na arte indígena "abstrata" repousa no que ela nos fala sobre a atitude cognitiva do artista e do público pretendido. Para os ameríndios, o universo é transformativo. Isto significa que o que vemos pode, repentinamente, mudar diante de nossos olhos. O mundo é composto por muitas camadas, os diversos mundos são pensados enquanto simultâneos, presentes e em contato, embora nem sempre perceptíveis. 0 papel da arte é o de comunicar uma percepção sintética dessa simultaneidade.

Ao analisar os desenhos indígenas, Roe chama a atenção para o padrão estilístico e não para unidades isoladas que o constituem. M inha investigação sobre o significado dos desenhos para os Kaxinawa confirma as percepções de Roe. Quando uma leitura iconográfica de unidades isoladas parece confusa e contraditória, é necessário introduzir uma leitura mais gestáltica ou estrutural dos padrões como um todo, o que proporciona, no caso kaxinawa, uma melhor compreensão dos seus usos e significados. A nalogias entre esse código visual e outros códigos verbais e nãoverbais que, juntos, formam o pano de fundo para a significação cognitiva e emocional do estilo artístico, são essenciais.

Outra ilustração da presença do perspectivismo na arte amazônica pode ser encontrada no estudo sobre os mitos, cestaria e canções yekuana (grupo Karib, da Venezuela) realizado por David Guss (1989). O autor decidiu sentar-se com os mais velhos e aprender a arte de trançar cestos. O que descobriu, por esse modo, foi que a vida para os Yekuana é como o trançado, ou, em outras palavras, que o trançar era a metáfora-chave para a vida entre este povo, e que fragmentos e partes do mito de origem eram 
trançados, proferidos e cantados pelos velhos todos os dias, no crepúsculo, quando sentavam juntos em um círculo.

O resultado da iniciação de Guss nas técnicas de trançado yekuana foi um profundo entendimento da ontologia yekuana.

“Com os desenhos abstratos este retrato simultâneo de uma realidade dual se torna muito mais complexo [que no caso do desenho figurativo]. Aqui também se mostra a imagem e a contra-imagem. No entanto, o que é realmente representado é a relação dinâmica entre os dois. Diferentemente das imagens estáticas dos desenhos figurativos, a estrutura cinética dessas formas cria um movimento sem fim entre elementos diferentes, puxando o espectador para dentro delas. A percepção agora se torna um desafio, com o espectador sendo forçado a decidir qual imagem é real e qual uma ilusão. A dualidade significada pela conquista dos cestos é perceptualmente incorporada na estrutura dos seus desenhos" (Guss 1989:122).

O estilo geral de desenho kaxinawa, designado kene kuin (desenho real), é similar ao estilo do trançado yekuana. O jogo entre imagem e contra-imagem expressa a idéia de duplicidade e co-presença das imagens reveladas e não-reveladas no mundo. N esse sentido, a ontologia kaxinawa, definindo as condições do ser e não-ser, é totalmente dependente do, e ligada ao, real processo perceptivo em que um agente particular esteja engajado.

\section{Imaginação perceptiva e percepção imaginativa}

“Para cada visão deve ser trazido um ol ho adaptado para o que deve ser visto" (Plotinos apud Furst 1972:142).

A questão da percepção e criatividade nativas somente pode ser entendida se captarmos como o pensamento nativo concebe a realidade. Levando em conta a ênfase ontológica fundamental da concepção amazônica do mundo na constante transformação de um ser em outro, somos obrigados a reinterpretar as relações entre percepção e criação, por um lado (com a percepção sendo, de alguma maneira, uma criação), e entre aparência, ilusão e realidade, por outro. Esta última questão nos leva ao problema dos estados de consciência. Desde que consciência é inconcebível sem uma consideração do estado do corpo, estados de consciência tornam-se estados do ser. Uso "estados do ser" em substituição à definição 
comumente utilizada para "estados de consciência" porque, desse modo, evitamos o perigo de inadvertidamente opor mente e corpo18.

Dessa maneira, a clássica questão nas teorias da percepção sobre a relação entre ilusão e realidade é substituída por uma consideração da relação entre estados diferentes de ser dos humanos assim como dos nãohumanos. Encontramos nas reflexões de Schweder (1991), sobre estados da mente e como estes estão relacionados, questões próximas da nossa problemática:

“Alguns argumentam, por exemplo, que a imaginação é oposta à percepção [...]. Outros sustentam que percepção é uma forma de imaginação (como a afirmação de que a percepção visual é uma 'construção'), enquanto outros argumentam que a imaginação é uma forma de percepção (por exemplo, que o sonho é o testemunho de outro nível de realidade). Outros ainda argumentam em ambas as direções, e dialeticamente, a favor da percepção imaginativa e da imaginação perceptiva." (Schweder 1991:37)

Um exemplo da relação entre percepção imaginativa e imaginação perceptiva pode ser encontrado em uma das características estilísticas mais marcantes do tecido desenhado feito pelas Kaxinawa: considerando que os padrões são interrompidos logo que começam a se tornar reconhecíveis no pano tecido, é necessária capacidade imaginativa para perceber sua continuação, através de uma visão mental. A técnica sugere que a beleza a ser percebida no exterior está presente no mundo invisível, no mundo das imagens a serem visualizadas pela criatividade perceptiva, tanto quanto - ou até mais que - na bel eza externalizada pela produção artística (ver foto 5).

Esse dispositivo estilístico revela um elemento importante do significado do desenho na ontologia kaxinawa: o papel desempenhado por este na transição entre percepção imaginativa e imaginação perceptiva, ou a transição de imagens percebidas pelos ol hos no cotidiano, para as imagens perceptíveis somente para o ol ho mental, o yuxin do olho. Desenho é um sinal do yuxin. A única resposta que dona M aria Sampaio, quase cega e portanto impossibilitada de fazer desenhos, me deu à pergunta sobre o significado dos desenhos foi que: "O desenho é a língua dos espíritos" (kene yuxinin hantxaki).

Os Shipibo (grupo pano do Ucayali) vão ainda mais longe na importância atribuída à percepção imaginativa quando afirmam que o corpo humano pode ser visto, quando se tem a capacidade de fazê-lo, como estando permanentemente desenhado. A pintura invisível funciona como arma- 


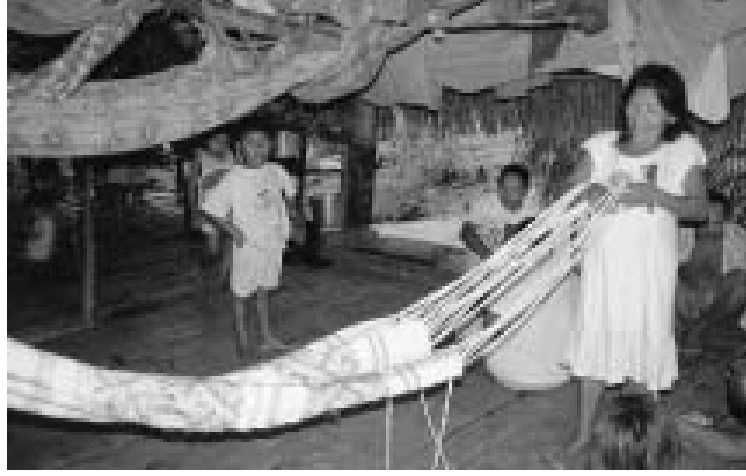

5 Entrega de uma rede com "motivo interrompido" Foto de Elsje Lagrou

dura contra a invasão da doença. Gebhart-Sayer (1986) interpreta a transição da visibilidade à invisibilidade na pintura corporal shipibo como medida de proteção usada por eles na sua relação de proximidade com não-nativos. Illius (1988), por outro lado, duvida que a pintura corporal tenha em algum momento sido usada fora do contexto ritual. Os não-Shipibo somente têm acesso à manifestação exterior dos belos e complexos padrões shipibo através da pintura na cerâmica e em panos (esses desenhos não são, como entre os Kaxinawa, tecidos, mas aplicados sobre o tecido pronto) (Roe 1980).

Os próprios Shipibo, entretanto, podem visualizar esses motivos, com alta significação cultural, sem precisar tê-los materialmente diante de si. $\mathrm{M}$ ulheres com conhecimento de desenho podem sonhar sobre o assunto — freqüentemente, com a ajuda de plantas (IIlius 1987:171), como o fazem as mulheres kaxinawa - , enquanto os homens, mais especificamente os xamãs, quando sob a influência da ayahuasca, visualizam, com a ajuda dos seus cantos, o desenho invisível que cobre a pele de seus pacientes (Gebhart-Sayer 1986). Illius e Gebhart-Sayer sugerem que a relação sinestésica entre canto e desenho na experiência com a ayahuasca diz mais respeito à melodia do que às palavras do canto.

Os Navajo dos Estados Unidos atribuem, igualmente, grande importância ao lado oculto da beleza. Witherspoon afirma:

“Para os Navajo a beleza não está tanto no olho do contemplador quanto na mente do seu criador e na relação entre o criador e o criado (isto é, o transformado, ou o organizado). O Navajo não procura beleza; a gera dentro de si e a projeta no universo. O Navajo diz shil hózhó 'beleza está comigo', shii hózhó ‘há beleza dentro de mim', shaa hózhó ‘beleza radia de mim'. A beleza não está 'lá fora', nas coisas a serem percebidas pelo contemplador perceptivo e apreciativo; é uma criação do pensamento. Os Navajo experien- 
ciam beleza primariamente através da expressão e criação, não através da percepção e preservação." (1997 [1977]:151)

Uma bem conhecida manifestação da filosofia de vida dos Navajo, e da atitude diante da arte que dela decorre, são as pinturas na areia, destruídas logo depois ou durante os rituais de cura. Os Navajo não vêem sentido na tentativa de tentar fixá-las ou conservá-las (através da fotografia, por exemplo), e consideram tal atividade como potencialmente perigosa. O perigo é ligado ao princípio básico que associa a vida ao movimento e a morte à ausência de movimento. $O$ prazer estético navajo reside no ato de criação, não na sua contemplação e conservação. Witherspoon completa:

\footnotetext{
“A sociedade navajo é uma sociedade de artistas (criadores de arte), enquanto a sociedade anglo-saxônica consiste primariamente em não-artistas que ol ham arte (consumidores de arte) [...]. O não-artista é uma raridade entre os Navajo. Além do mais, os artistas navajo integram suas aspirações artísticas nas suas outras atividades. A vida não é uma modalidade da arte, mas a arte uma maneira de viver." (1997 [1977]:153)
}

M ais importante que a maneira como o conhecimento é estocado em objetos externos, é o modo como as pessoas o incorporam, tanto no caso do conhecimento produtivo como da arte de viver bem e sem doença. Da mesma maneira, para os Kaxinawa, a arte é, como a memória e o conhecimento, incorporada, e os objetos não são senão extensões do corpo. Esta prioridade explica por que as expressões estéticas mais elaboradas dos grupos indígenas são ligadas à decoração corporal: pintura corporal, arte plumária, colares e enfeites de miçanga, roupas e redes tecidas com elaborados motivos decorativos. Os Kaxinawa não estocam suas produções artísticas. Como os Navajo, estão convictos de que objetos rituais perdem seu sentido e sua beleza (assim como seu dua, brilho, encanto) depois de terem sido usados. Um exemplo é o banco ritual utilizado pelos iniciantes durante o rito de passagem. Se durante o ritual o banco é belamente pintado e reservado somente ao iniciando, depois ele se torna um simples banco, cuja decoração desaparece lentamente, que pode ser usado por qualquer homem (no cotidiano, as mulheres não se sentam em bancos, mas em esteiras).

Outra conseqüência da relação dinâmica entre percepção imaginativa e imaginação perceptiva se expressa na vida real e na percepção em geral, retirando todo sentido à tradicional oposição entre aparência e essência ou entre realidade e ilusão. Toda percepção tem algum tipo de 
existência específica. Isto não significa que imagens e corpos ocupem a mesma posição na ontologia kaxinawa. A diferença entre tipos de perceptos é produzida no interior de um quadro de referência que leva em conta os distintos estados do ser.

O estado do ser funde estado do corpo e estado da mente. Por isso, quando alguém, entre os Kaxinawa, vê fantasmas, yuxin ou outras aparições que não pertencem à esfera da percepção cotidiana, ninguém questionará o fato de ele ou ela realmente ter visto alguma coisa; se a percepção foi ou não uma ilusão, isto é, uma "alucinação" , é algo não passível de discussão. Ter alucinações significa perceber (através de um ou mais sentidos) o que não existe na "realidade". O conceito de "alucinação" não existe na língua kaxinawa porque a concepção e a percepção da "realidade" são radicalmente diferentes.

O conceito kaxinawa mais próximo de nossas noções de "ilusão" e "alucinação" seria o de "mentira" (txaniki) e, dependendo da seriedade da experiência, "brincadeira" (beyuski). Quando é dito que uma pessoa ou um espírito da floresta estava somente "brincando", nenhuma conseqüência perigosa é esperada desse evento. Mentir, por outro lado, pode ser mais perigoso. São os estrangeiros, trapaceiros e espíritos que mentem e enganam. Este é um método comum para distrair e guiar pessoas que andam sozinhas, inadvertidamente, por caminhos que irão extraviá-las, fazendo com que percam a orientação e a capacidade de retornar ao mundo conhecido.

É importante frisar que aquele que "mente" sobre as percepções que não se encaixam no mundo cotidiano dos corpos sólidos é, geralmente, não a pessoa que viu algo e relatou o que viu para seus companheiros, mas o agente que produziu o fenômeno percebido. Esses agentes, designados yuxin, são seres indefinidos e mutáveis desprovidos de um corpo sólido, mas dotados da capacidade de produzir imagens e aparições que amedrontam e confundem os humanos. Estes seres, dos quais os mais poderosos são os yuxibu (-bu é um pluralizador de yuxin, significando multiplicidade e magnitude, concebida aqui em termos de poder), têm tanta potência que são capazes de produzir imagens e até mesmo transformá-las no que desejam. É hábito deles aplicar golpes nos humanos e trapaceá-los, capturando-os e transferindo-os para um outro mundo: um mundo percebido e experienciado diferentemente. Uma imagem usada para expressar a ultrapassagem desse limiar é a do yuxin que espreme a seiva de uma planta medicinal nos olhos de uma pessoa e a transporta para sua própria aldeia.

Dessa forma de concepção resulta que o que necessita ser determinado para a compreensão de um caso extraordinário de percepção é o estado específico do ser perceptor, assim como a qualidade do ser perce- 
bido e do contexto da percepção. A pessoa pode estar doente ou melancólica ou, ainda, em processo de tornar-se xamã. Pode, inclusive, encontrar-se em um estado perfeitamente normal, mas em um contexto propício para que fenômenos, normalmente invisíveis, se manifestem, por exemplo ao cair da noite ou durante uma tempestade com relâmpagos. Outra situação em que se pode perceber imagens invisíveis é durante o ritual de ingestão da ayahuasca.

Estes exemplos indicam que as diferentes possibilidades de percepção estão ligadas a estados particulares do ser. Alguns destes estados implicam tão al to grau de imitação e contato com a alteridade, incluindo a mudança da ação e da forma corporal, que pouco sobrou daquilo que poderíamos designar por "eu real", imerso na atividade corporal, na interação social e nas rotinas diárias. O chamado da floresta, com seus animais/yuxin querendo transformar sua vítima seduzida em um dos seus, é igualado em perigo ao chamado da cidade, com sua bebida, a cachaça, e sua fascinante variedade de habitantes (nawa).

Do precedente, podemos concluir que, para os Kaxinawa, todas as imagens são, de algum modo, 'duplos' dos seres aos quais se referem. Desse modo, eles não se colocam o problema de distinguir o verdadeiro e o ilusório na percepção, como tem feito a tradição filosófica desde Platão. Vernant (1991:165-195) afirma que as imagens começaram a ocupar um lugar diferente no pensamento grego a partir do período em que se democratizou o uso da escrita, e ilustra esta passagem com os escritos de Platão, que, contemporâneo do processo de mudança, defendia a contemplação distanciada contra o sistema educacional tradicional, baseado nos métodos da mímesis. O ideal educacional de Platão era, nas suas próprias palavras, realizável somente através do uso da escrita.

Platão completa a ruptura com o sistema de transmissão oral do conhecimento, que incluía como método de memorização a recitação oral de cantos poéticos, habitualmente acompanhada por dança. Este método promovia o aprendizado através da empatia e identificação do público com o ator ou cantor que representava os papéis em questão. $O$ método mimético carecia, na visão de Platão, do distanciamento necessário para a busca do conhecimento objetivo, distanciamento este que somente a escrita poderia criar. A crítica de Platão com relação à mímesis levou-o a uma reformulação da noção de imagem que marcou, nas palavras de Vernant, "um estágio no que poderia ser chamado a elaboração da categoria da imagem no pensamento ocidental." (1991:174)

A 'imagem' se torna uma pura aparência superficial que aliena o estudante da verdadeira 'essência' do ser, que é estática. A performance 
personalizada, usada no processo de memorização e transmissão do conhecimento oral, mergulharia o estudante no fluxo sensível do devir, evocado através da linguagem dramática, rítmica e emocional dos sofistas, e inviabilizaria dessa maneira qualquer possibilidade de reflexão e distanciamento por parte do receptor da informação.

Sob a pena de Platão, sofistas, poetas e atores foram acusados de se perderem na multiplicidade das aparências sensíveis, pertencentes ao domínio da mera opinião (doxa), e de cegarem-se assim para o verdadeiro conhecimento do ser (epistéme), procurado pelo filósofo. A verdade para o filósofo residiria na idéia da 'essência', da estrutura interna do ser, que é única e permanente, e independe do ponto de vista do observador. Esta posição filosófica pressupõe a existência de uma realidade objetiva e lógica, exterior ao sujeito e governada por leis universais, cognoscíveis unicamente pelo intelecto. É um modo de pensar sobre a relação entre ser e parecer que mudou radicalmente o estatuto da imagem no pensamento grego arcaico. Detive-me neste tópico porque clarifica al gumas das idéias sobre realidade e ilusão que ocuparam o pensamento ocidental por muito tempo, e que foram desafiadas somente pelo advento das teorias psicológicas sobre o papel ativo da imaginação nos fenômenos da percepção19. Cito Vernant:

“Para o pensamento arcaico, a dialética de presença e ausência, igualdade e diferença, se desenvolve na dimensão extracotidiana que o eidolon, sendo um duplo, contém, no milagre de algo invisível que pode ser vislumbrado somente por um instante. Esta mesma dialética é reencontrada em Platão. No entanto, uma vez transposta para um vocabulário filosófico, não somente muda seu registro e assume um novo significado, mas os termos são também de alguma maneira invertidos. A imagem, um 'segundo objeto similar', sendo definida em alguns sentidos como Igual, também refere ao Outro. Não é confundida com o modelo porque, tendo sido denunciada como falsa, nãoreal, não mais carrega, como no caso do eidolon arcaico, a marca da ausência, do além e do invisível, mas o estigma de um não-ser realmente não-real. Em vez de expressar a irrupção do sobrenatural na vida humana, do invisível no visível, o jogo do Igual e o Outro acaba circunscrevendo o espaço do fictício e ilusório, entre os pólos do ser e não-ser, entre o verdadeiro e o fal so. A 'aparição', com os valores religiosos que a investem, é substituída pelo 'parecer', uma aparência, um puro 'visível' onde a questão não é a de fazer uma análise psicológica, mas de determinar seu status do ponto de vista de sua realidade, de definir sua essência a partir de uma perspectiva ontológica" (1991:168). 
Dessa maneira, o sensível torna-se ilusório e falso, enquanto o inteligível, seu oposto, se torna a única realidade. A idéia da imagem como ilusão e a possibilidade de ver o que não é real estão na base dos conceitos de 'alucinação' e 'representação'. A idéia do faux-semblant e da representação artística é conseqüência dessa "secularização" da imagem. No momento dessa divisão epistemológica, a imagem começa a simular a presença de algo sem nenhuma partilha metonímica na qualidade (ou 'essência') do representado. A noção de representação supõe a ausência daquilo que substitui, assim como supõe uma diferença qualitativa entre a coisa representada e a imagem que a substitui. A imagem não tem nenhuma realidade além de ser semel hante à coisa a que se refere.

A busca do 'puro espírito' (ou idéia), presente somente para si mesmo, poluindo-se quando imerso na matéria e nas formas cambiáveis da vida, ocupou o pensamento ocidental até o século XVIII, quando começa a ser questionada pela hermenêutica e pela emergência das ciências sociais. Teorias modernas da percepção reintroduziram a noção de agência e as capacidades criativas da mente humana no conceito de imagem e, desde então, o papel da imaginação e a relação entre realidade e aparência começaram a ser reavaliados. O problema do sentido da ficção e da mímesis está na ordem do dia na antropologia, nas artes e em outras áreas das ciências humanas. Desse modo, nos tornamos mais bem preparados para aceitar uma leitura e um significado diferente da vida das imagens sugeridas pelos Kaxinawa.

Em resumo, à guisa de conclusão, algumas das características específicas do pensamento kaxinawa sobre a experiência visual. A visão é concebida como um processo dinâmico, e nunca passivo ou estático. Na produção de desenhos, não se procura fixar o ponto de vista de quem ol ha. Visto que não há fundo ou figura em que os olhos possam pousar sua atenção, e sim a dinâmica desassossegada da percepção alternada de figura e contrafigura, o ol har do perceptor é sugado para dentro da kinestesia do desenho geométrico (cf. Guss 1989:122). Vemos assim que a 'escrita' (kene) kaxinawa, uma 'inscrição' do sentido na acepção ampla da palavra (cf. Derrida 1973:153-154), supõe um conceito de visão diferente daquele que sustenta o lugar da visão, assim como da pintura e da escritura, na cultura clássica ocidental, onde a escrita era considerada antes de tudo como técnica que permitia fixar o fluxo do pensamento e da fala em uma forma visual permanente, tornando-o dessa maneira suscetível à observação distanciada e objetivada (Ricoeur 1981:183-211; Vernant 1991).

Os Kaxinawa consideram o conhecimento como algo incorporado. Assim, quando um Kaxinawa se refere ao conhecimento contido nos ca- 
dernos do etnógrafo, não se refere às letras (kene) no papel, mas ao papel que contém as letras. Por esta razão, chamam papel de conhecimento (una) ${ }^{20}$. Como alusão à sua concepção corporal do conhecimento, comentários irônicos fizeram-me entender que, na visão dos Kaxinawa, a preocupação dos brancos com o armazenamento de conhecimento em objetos fora dos seus corpos fez com que seus corpos parassem de conhecer. Os livros são contentores de conhecimento, una; as fitas cassete são 'captadores da voz', huibiti; e as câmeras acumulam imagens perfeitas de corpos, ou seja, yuxin, e são por esta razão chamadas de 'captadores de yuxin' (yuxinbiti). "Mas para aprender 'de verdade'...", disse-me Augusto em uma das últimas tardes em que trabalhamos juntos, e, em vez de prosseguir sua frase, me pegou no braço e começou a cantar, dançando.

\section{Conclusão: Bateson na Amazônia}

"Arte é o espelho ustório (burning glass) do sol do significado" (Roy Wagner 1986:27).

Para concluir e sintetizar as idéias acima expostas, farei dialogar meus dados de forma extremamente sintética ${ }^{21}$ com as reflexões de Bateson (1977) sobre a comunicação na arte em um artigo chamado "Grace”, , "G raça”. C omo salientado acima, o estilo gráfico e a arte plumária kaxinawa correspondem às idéias básicas deste povo sobre o significado da similaridade e da diferença (a relação entre o eu e o outro), assim como sobre a relação das pessoas com (outros seres no) o mundo (a relação entre a pessoa e o ambiente). Como no exemplo de Bateson, uma pintura balinesa, essas idéias básicas não são expressas de modo unívoco e denotativo, como seria o caso em uma representação alegórica de idéias abstratas, mas de modo sintético e polifônico, permitindo assim, simultaneamente, leituras e interpretações diferentes e complementares. No caso da pintura de Bali, a mensagem mais importante não está na procissão de cremação, tema representado no quadro, nem no simbolismo fálico subjacente à imagem da torre de cremação, mas na combinação destes níveis diferentes, assim como na composição global da cena, onde a agitação das figuras no fundo do quadro contrasta com e corresponde à tranqüilidade das imagens na parte superior. Assim, conclui Bateson:

“Em última análise este quadro pode ser lido como uma afirmação de que escolher entre turbulência e serenidade, como projeto humano, seria um grave 
erro. Conceber e executar o quadro fornece uma experiência que expõe este erro. A unidade e a integração do quadro afirmam que nenhum destes dois pólos contrastantes pode ser escolhido com a exclusão do outro, porque são mutuamente dependentes. Esta verdade profunda e geral é dita simultaneamente com relação à sexualidade, à organização social e à morte" (1977:194).

De modo similar, a expressão estética kaxinawa não 'fala' específica ou exclusivamente sobre as relações sociais (o igualitarismo, a interdependência ou a hipotética permutabilidade das posições sociais) ou sobre a complementaridade constitutiva das metades e do gênero (o dualismo do pensamento social sendo expresso nas cores contrastantes das figuras e contrafiguras entrelaçadas). A estética kaxinawa também não é uma referência exclusiva à interdependência dos lados visíveis e invisíveis do mundo, ou à união sexual - apesar de esta ser uma das leituras possíveis (sugeridas por al guns informantes) das linhas que se unem. A expressão estética é, entretanto, uma comunicação sintética que se refere a todos esses níveis simultaneamente.

E esta é, segundo Bateson, a razão de essas expressões estéticas poderem ser chamadas de 'boa arte': em lugar de serem meras 'representações' ou ilustrações de um conhecimento denotativo sobre o mundo, que poderia ser mais bem expresso em palavras, a boa arte cria algo novo, uma nova maneira de perceber a relação entre o eu, o outro e o mundo. É a consciência sintética e referência simultânea da interconexão de diferentes níveis existenciais que constitui a especificidade da comunicação não-verbal. O código visual comunica a compreensão e percepção de uma ligação existencial que é consciente em um nível que escapa ao discurso verbal, pela simples razão de que é impossível verbalizar tudo de uma só vez.

Essa maneira de entender a arte, sugerida por Bateson, é interessante por explicitar sua especificidade e por realçar a necessidade de uma tradução para que seu significado possa ser integrado no discurso verbal. M ostra, igualmente, seu efeito estimulante sobre o pensamento analítico, por dar início a um processo de reflexão e associação que serve para ampliar o circuito mental e o campo de percepção cognitiva.

Penso, entretanto, que não devemos esquecer outro aspecto importante da comunicação (não-verbal), que reside na sua necessária abertura de sentido (I'oeuvre ouverte). N enhum trabal ho ou expressão carrega em si a totalidade dos seus sentidos. Não há nenhum sentido inerente, secreto ou absoluto a ser descoberto, a não ser no encontro entre o observado e o observador. 
Recebido em 20 de novembro de 2001

A provado em 25 de fevereiro de 2002

Elsje Maria Lagrou é professora adjunta do Programa de Pós-Graduação em Sociologia e Antropologia, IFCS/UFRJ, e doutora pela University of St. Andrews (Escócia) e pela Universidade de São Paulo. Realizou pesquisa entre os Kaxinawa do Acre e publicou artigos sobre xamanismo, ritual e outros aspectos da etnografia desse povo em diversas revistas científicas e coletâneas.

\section{Notas}

* Este texto é baseado em idéias centrais desenvolvidas na minha tese de doutorado sobre os Kaxinawa do Alto Rio Purus, Acre (1998). A realização da tese foi possível graças a uma bolsa da CAPES, ao auxílio para pesquisa da FAPESP, ao Sutusoma Fund e a um ano de bolsa da Universidade de St. Andrews.

1 A parte introdutória deste texto é uma síntese de idéias expostas de forma mais extensa em texto publicado em Fazendo Antropologia no Brasil (Lagrou 2001). Foi necessária a retomada das características básicas da organização social e conceitual kaxinawa para poder explicitar sua relevância para a discussão da arte.

2 As traduções do original são de minha autoria.

3 Os Kaxinawa utilizam este pluralizador para as gerações alternadas de doadores de nomes que constituem seu sistema onomástico: awabu [aqueles da anta], yawabu [aqueles da queixada], dunubu [aqueles da cobra], kanabu [aqueles da arara azul], awabuaibu [as mulheres que são do tapir] etc.

4 Os Pano, e os Kaxinawa em particular, apresentam uma variação no colorido mosaico das diferentes maneiras de lidar com a alteridade, pois se situam em algum lugar entre o concentrismo tupi e o diametralismo jê (veja Lagrou 2001:9597 e Viveiros de Castro 1993). Vale ressaltar que uso os 'J ê' aqui como uma abstração com fins heurísticos para a compreensão dos Pano, seguindo uma sugestão feita por Viveiros de Castro (1993:204). Tenho, no entanto, plena consciência da enorme variabilidade interna ao complexo jê com relação à qualidade concêntrica e/ou diametral da relação entre as metades, e uma análise mais fina da própria literatura jê permitiria talvez situar os Kaxinawa como uma variação no próprio mosaico jê, em vez de somente como transição entre a clássica oposição jê/tupi, mas esta é uma proposta para outro artigo. 
5 O pertencimento dos nomes às gerações alternadas parece ser menos importante que o pertencimento à metade (M cCallum 1989). Este é o caso para os Kaxinawa brasileiros da Área Indígena do Alto Purus, mas não foi confirmado pelos especialistas para os Kaxinawa do Peru (Kensinger 1995; Deshayes e Keifenheim 1982) que enfatizam um ideal de troca de irmãs, especialmente na ocasião da fundação de uma nova aldeia. Para outros grupos pano, entretanto, Erikson menciona que "le 'point faible' de la structure 'kariera' pano" é "la rupture introduite par les marriages obliques avec le frère de la mère." (1986:205) A relativa prioridade de sistemas com ênfase nas seções (gerações alternadas) ou nas metades tem sido tema de acalorado debate entre 'panólogos'. Se a tendência é recente ou expressa, pelo contrário, uma característica originalmente protopano não tenho como afirmar, mas não há dúvida de que os Kaxinawa por mim estudados enfatizam pouco as seções, e o sistema kariera não me parece exercer influência sobre o sistema gráfico (veja Lagrou 1998, para uma discussão mais elaborada do debate a respeito desse tópico na literatura pano).

6 A mesma lógica de consubstancialidade pode ser encontrada entre os Cubeo (Goldman 1979), Piaroa (Overing 1975), A pinayé (Da M atta 1976), Airo-Pai (Belaunde 1992), Piro (Gow 1991), para citar apenas alguns exemplos.

7 O conceito yuxin - ao qual dedico longa análise em Lagrou (1998) - é complexo e não encontra plena expressão nas palavras 'alma', 'fantasma' ou 'espírito', apesar de poder ser traduzido por estes termos, dependendo do contexto. 0 corpo humano é habitado por vários tipos de yuxin: o yuxin do olho (expressão do yuxin kuin, o mais vital dos yuxin de uma pessoa), do corpo (a sombra), das fezes, da urina. O corpo acordado e saudável está com todos os seus yuxin presentes. A pessoa morre quando o yuxin do ol ho sai para sempre. Yuxin, por outro lado, é também o termo usado para se referir a seres desenraizados, sem lugar de moradia fixo, sem relações que constituam sua pessoa e seu corpo. Uma conseqüência dessa existência 'solta' é a transformabilidade de seu corpo, de sua aparência. É a esta última modalidade de yuxin que meu interlocutor se refere no trecho citado acima. Outra acepção do conceito yuxin não Ihe confere o status de 'ser', mas de 'energia difusa' que permeia todos os seres vivos, sendo responsável pela possibilidade de transformação de um ser em outro.

8 Veja Becker (1995) e Strathern (1988) para reflexões sobre povos melanésios próximas destas aqui expostas para os ameríndios.

9 Ver nota 7.

10 Ver nota 4.

11 Veja Århem (1996), Lima (1996), Viveiros de Castro (1996), Lagrou (1998; 2001). Para a oposição fundante entre caça e caçador, veja Vilaça (1992). A idéia central do 'perspectivismo' é de que diferentes seres podem ter perspectivas não correspondentes sobre a natureza de suas interações. Assim, um determinado animal se percebe a si mesmo como pessoa, enquanto o caçador o percebe como caça, 
o mesmo podendo ocorrer com o ser humano ao se encontrar com um ser sobrenatural que o considera sua presa. Este tema, extremamente recorrente na bibliografia amazônica, foi elaborado e promovido a um nível de abstração maior por Viveiros de Castro (1996), visando dar conta de uma qualidade por ele considerada específica e geral para o pensamento ameríndio. Desde então ganhou caráter de conceito na literatura especializada. Para a elaboração do conceito, o autor inspirou-se em duas etnografias que apontavam a qualidade perspectiva das relações entre humanos e animais como extremamente relevantes para os povos ali estudados: os J uruna (Lima 1996) e os Makuna (Århem 1996).

$12 \mathrm{O}$ oposto ocorre no imaginário indo-europeu e seus mitos sobre gêmeos, em que a fascinação pelos gêmeos deriva exatamente de sua qualidade de intercambialidade hipotética. A especulação indo-européia sobre gêmeos está intrigada pela possibilidade da identidade dividida (split identity), enquanto nos mitos ameríndios a idéia de duplicidade já carrega consigo a idéia da diferença (LéviStrauss 1991:299-320).

13 O conceito yuxibu aproxima-se do de yuxin (veja nota 7), mas é caracterizado por uma maior especificidade. O pluralizador -bu indica maior poder de transformação e, portanto, menor dependência dos corpos cujas formas pode assumir. Desse modo, usa-se o conceito yuxibu (no tempo de Capistrano traduzido como ‘grande diabo') para se referir a seres sobrenaturais ou sobre-humanos, donos da água, do céu e da terra. Estes seres são caracterizados pela velocidade com que são capazes de se deslocar e pela liberdade com que assumem e criam novas aparências.

14 Dawson (1975) nota a ocorrência de detalhes assimétricos na tecelagem kaxinawa.

15 O fenômeno da transformação de um motivo em outro foi igualmente notado por Keifenheim (1996).

16 O mesmo artifício estilístico foi notado por Müller (1990) entre os Asurini (cf. Lagrou 1991).

17 Atualmente, a produção de adornos plumários nas aldeias que visitei é rara e a qualidade da produção não se compara com os espécimes encontrados nas coleções feitas por Schultz e Chiara em 1950-51 (M useu Paulista) e Kensinger nos anos 50 e 60.

18 A sugestão para usar o conceito de "estados do ser" tomei emprestada de Gonçalves (2001:177, 265-266).

19 O conceito de 'imaginação', enquanto associado à capacidade da mente de produzir imagens, surgiu no segundo século da nossa era (Vernant 1991:185).

20 Veja Gow (1990) para uma abordagem semelhante referindo-se, também, à escrita entre os Piro. 
21 Para uma elaboração mais extensa das idéias de Bateson sobre o modo artístico de comunicar, ver Lagrou (1998:181-200).

\section{Referências bibliográficas}

ÅRHEM , Kay. 1996 [1993]. "The Cosmic Food Web: Human-Nature Relatedness in the Northwest Amazon". In: P. Descola e G. Pálsson (orgs.), Nature and Society. Anthropological Perspectives. London/New York: Routledge. pp. 185-204.

BARTHES, Roland. 2000 [1980]. A Câmera Clara. Rio de J aneiro: Ed. Nova Fronteira.

BATESON, Gregory. 1977. Vers une Écologie de l'Esprit. Paris: Seuil.

BECKER, Anne. 1995. Body, Self and Society. The View from Fiji. Philadel phia: University of Pennsylvania Press.

BELAUNDE, Luisa Elvira. 1992. Gender, Commensality and Community among the Airo-Pai of West A mazonia (Secoya, Western-Tukanoan Speaking). Ph.D. Dissertation, London School of Economics.

BOAS, Franz. 1955 [1928]. Primitive Art. New York: Dover Publications.

CALAVIA, Oscar. 1995. O Nome e o Tempo dos Yaminawa. Etnologia e História dos Yaminawa do Rio Acre. Tese de Doutorado, Universidade de São Paulo.

CAPISTRANO DE ABREU, J oão. 1941 [1914]. Rã-txa hu-ni-kuĩ: A Língua dos Caxinauás do Rio I buaçú. Rio de Janeiro: A Sociedade de Capistrano de Abreu.

CARNEIRO DA CUNHA, Manuela. 1978. Os M ortos e os Outros. São Paulo: Hucitec.
CLASTRES, Pierre. 1974. La Société contre I'État. Paris: Les Éditions de Minuit. . 1982. A rqueologia da Violência. São Paulo: Brasiliense.

DA M ATTA, Roberto. 1976. A pinayé. Um M undo Dividido. Petrópolis, RJ : Editora Vozes.

DAWSON, Alice. 1975. "Graphic Art and Design of the Cashinahua". In: J . P. Dwyer (org.), The Cashinahua of Eastern Peru. Philadelphia: Haffenreffer Museum of Anthropology. pp. 131-150.

DERRIDA, J acques. 1973 [1967]. Gramatologia. São Paulo: Ed. Perspectiva.

DESCOLA, Philippe. 1987. La Nature Domestique: Symbolisme et Praxis dans I'Écologie des Achuar. Paris: Éditions de la Maison de Sciences de I'Homme.

DESHAYES, Patrick e KEIFENHEIM, Barbara. 1994 [1982]. Penser l'Autre chez les Indiens Huni Kuin de I'Amazonie. Paris: L'Harmattan.

DUM ONT, Louis. 1980. Homo Hierarchicus. Paris: Plon.

ERIKSON, Philippe. 1986. “Altérité, Tatouage et Anthropophagie chez les Pano: La Belliquese Quête du Soi". J ournal de la Société des A méricanistes, LXXII:185-210.

. 1992. “Uma Singular Pluralidade: A Etnohistória Pano". In: História dos Índios do Brasil. São Paulo: Companhia das Letras/FAPESP/SMC. pp. 239-252. 
FURST, Peter. 1972. Flesh of the Gods: The Ritual Use of Hallucinogens. Prospect Heights, Illinois: Waveland Press.

GEBHART-SAYER, Angelika. 1986. “Una Terapia Estética: Los Diseños Visionarios del Ayahuasca entre los Shipibo-Conibo". América Indígena, XLVI:189-218.

GOLDM AN, Irving. 1979 [1963]. The Cubeo. Indians of the N orthwest Amazon. Urbana: The University of IIIinois Press.

GONÇALVES, M arco Antonio. 2001. Um M undo Inacabado. A ção e Criação em uma Cosmologia Amazônica. Etnografia Pirahã. Rio de J aneiro: Ed. UFRJ .

GOW, Peter. 1988. “Visual Compulsion; Design and Image in Western Amazonian Art". Revindi:19-32.

. 1990. “Could Sangana Read? The Origin of Writing among the Piro of Eastern Peru". History and Anthropology, 5:87-103.

. 1991. Of Mixed Blood. Kinship and History in Peruvian Amazonia. Oxford: Oxford University Press.

GUSS, David. 1989. To Weave and Sing. Art, Symbol and Narrative in the South American Rain Forest. Berkeley, Los Angeles/London: University of California Press.

ILLIUS, Bruno. 1987. Ani Shinan: Schamanismus bei den Shipibo-Conibo (Ost-Peru). Tübingen: Verlag S\&F. . 1988. “'Die Grosse Boa'. Kunst und Kosmologie in der Shipibo-Conibo". In: M. Münzel (ed.), Die Mythen Sehen. Frankfurt: Frankfurt Verlag. pp. 705-735.

KEIFENHEIM, Barbara. 1990. “Nawa: Un Concept Clé de I'Altérité chez les Pano". Journal de la Société des Américanistes, 76:79-94.

. 1992. “Identité et Altérité chez les Pano". Journal de la Société des Américanistes, 78(2):79-93.
1996. Snake Spirit and Pattern Art. Ornamental Visual Experience among the Cashinahua Indians of Eastern Peru. M anuscrito.

KENSINGER, Kenneth. 1995. How Real People Ought to Live. The Cashinahua of Western Peru. Illinois: Waveland Press.

LAGROU, Elsje Maria. 1991. Uma Etnografia da Cultura Kaxinawá: Entre a Cobra e o Inca. Dissertação de M estrado, PPGAS/Universidade Federal de Santa Catarina. . 1998. Caminhos, Duplose Corpos. Uma A bordagem Perspectivista da Identidade e Alteridade entre os Kaxinawa. Tese de Doutorado, Universidade de São Paulo. (Traduzida da versão inglesa: Cashinahua Cosmovision. A Perspectival Approach to Identity and Alterity. Ph.D. Dissertation, University of St. Andrews.)

. 2001. "Identidade e Alteridade a partir da Perspectiva Kaxinawa" . In: Fazendo Antropologia no Brasil. Rio de J aneiro: D, P \& A Editora/CAPES/ PROIN. pp. 93-127.

LEACH, Edmund. 1954. Political Systems of Highland Burma. Cambridge: Harvard University Press.

LÉVI-STRAUSS, Claude. 1973 [1955]. Tristes Tropiques. Paris: Plon.

. 1991. Histoire de Lynx. Paris: Plon.

LIMA, Tânia Stolze. 1996. “O Dois e seu Múltiplo: Reflexões sobre o Perspectivismo em uma Cosmologia Tupi". Mana, 2(2):21-47.

MAYBURY-LEWIS, David (org.). 1979. Dialectical Societies: The Gê and Bororo of Central Brazil. Cambridge: Harvard University Press.

MCCALLUM, Cecilia. 1989. Gender, Personhood and Social Organization amongst the Cashinahua of Western Amazonia. Ph.D. Dissertation, London School of Economics.

MÜLLER, Regina. 1990. Os Asuriní do 
Xingu. História e Arte. Campinas, SP: Unicamp.

OVERING, J oanna. 1975. The Piaroa. A People of the Orinoco Basin. A Study in Kinship and Marriage. Oxford: Clarendon Press. . 1984. "Dualisms as an Expression of Difference and Danger: M arriage Exchange and Reciprocity among the Piaroa of Venezuela". In: K. Kensinger (org.), M arriage Practices in Lowland South America. Urbana/Chicago: University of Illinois Press. pp. 127-155.

. 1985. "There Is No End of Evil: The Guilty Innocents and their Fallible God". In: R. Parkin (org.), The Anthropology of Evil. Oxford: Blackwell Publications. pp. 244-278.

.1986. “Images of Cannibalism, Death and Domination in a 'Non-Violent' Society". J ournal de la Société des Américanistes, LXXII:133-156.

. 1993. "Death and the Loss of Civilized Predation among the Piaroa of the Orinoco Basin". L'Homme, 126128:191-211.

RABINEAU, Phyllis. 1975. "Artists and Leaders: The Social Context of Creativity in a Tropical Forest Culture". In: J. P. Dwyer (org.), The Cashinahua of Eastern Peru. Philadelphia: Haffenreffer Museum of Anthropology. pp. 87-109.

RICOEUR, Paul. 1981. Hermeneutics and the Human Sciences. Cambridge: Cambridge University Press.

ROE, Peter. 1980. “Art and Residence among the Shipibo Indians of Peru: A Study in Microacculturation". American Anthropologist, LXXXII: 42-71.

. 1987. Impossible Marriages: Cashi Yoshiman Ainbu Piqui (The Vampire Spirit Who Ate a Woman) and Other Animal Seduction Tales among the Shipibo Indians of the Peruvian J un- gle. Trabalho apresentado no Fifth International Symposium on Latin A merican Indian Literatures (LAILA). Ithaca, New York.

SCHWEDER, Richard. 1991. Thinking through Cultures. Expeditions in Culture Psychology. Cambridge: Harvard University Press.

STRATHERN, Marilyn. 1988. The Gender of the Gift. Los Angeles: University of California Press.

TAUSSIG, Michael. 1993. Mimesis and Alterity. A Particular History of the Senses. New York/London: Routledge.

TOWNSLEY, Graham. 1988. Ideas of Order and Patterns of Change in Yaminhaua Society. Ph.D. Dissertation, Cambridge University.

VERNANT, J ean-Pierre. 1991. M ortals and Immortals. Collected Essays. New J ersey: Princeton University Press.

VILAÇA, A parecida. 1992. Comendo como Gente. Formas do Canibalismo Wari. Rio de J aneiro: Editora UFRJ / Anpocs.

VIVEIROS DE CASTRO, Eduardo. 1986. Os Araweté, os Deuses Canibais. Rio de J aneiro: Zahar/Anpocs. . 1993. "Alguns A spectos da A finidade no Dravidianato Amazônico". In: E. Viveiros de Castro e M. Carneiro da Cunha (orgs.), A mazônia. Etnologia e História Indígena. São Paulo: NHII/USP/FAPESP. pp.149-210. . 1996. “Os Pronomes Cosmológicos e o Perspectivismo Ameríndio". Mana, 2(2):115-144.

WAGNER, Roy. 1986. Symbols that Stand for Themselves. Chicago/ London: University of Chicago Press. WITHERSPOON, Gerald. 1997 [1977]. Language and Art in the Navajo Universe. Ann Arbor: The University of Michigan Press. 
Resumo

A intenção deste texto é demonstrar, através do diálogo com vários antropólogos que pensaram a arte enquanto linguagem específica, como a perspectiva kaxinawa sobre o entrelaçamento da alteridade e da identidade no tecido da vida se expressa na sua arte. Com esse objetivo, é explorado o modo como a alternância entre figura e fundo chama a atenção para a presença simultânea da figura e de seu contrário corolário na pintura corporal e tecelagem, assim como na arte plumária dos homens, onde a relação entre simetria e assimetria recebe um tratamento diferente mas complementar ao da arte feminina.

Palavras-chave Etnologia, Antropologia da Arte, Cosmologia, Kaxinawa

\section{Abstract}

Turning to various anthropologists who have approached art as a specific type of language, this paper aims to show how the Cashinahua vision of the interweaving of alterity and identity in the fabric of life is expressed in their body painting and textile work. Here, the alternation between figure and ground calls attention to the simultaneous presence of both the figure and its counterfigure, just as in men's plumary art where the relation between symmetry and asymmetry receives a different but complementary treatment to the artwork produced by women.

Key words Ethnology, Anthropology of Art, Cosmology, Cashinahua 